Acta vet. scand. $1974,15,445-447$.

Brief Communication

\title{
QUANTITATIVE DETERMINATION OF SHORT-CHAIN FATTY ACIDS IN RUMEN FLUID*
}

Determination of volatile fatty acids (VFA) in rumen fluid has for years involved the problem of suitable analytical methods to be carried out quantitatively and rapidly. Previously, the author has published the qualitative part of an applicable method using gas-solid adsorption chromatographic determination on uncoated Chromosorb 101 (Jensen 1973), and will further provide some information concerning column characteristics, recovery and reproducibility.

Analyses of a standard solution, performed with working conditions as previously described, gave the relative retention time of the fatty acids shown in Table 1, indicating a good separation between the peaks. The absolute retention time of the internal standard (isocaproic acid) was $8 \mathrm{~min}$. The relative detector response factor $\mathrm{R}$ of each fatty acid according to the internal standard per unit weight was determined 4 times a day, and the average values obtained from 10 subsequent days of analyzing are also shown in Table 1 . A test of variance reveals that $R$ has to be determined every day in order to assure a proper basis

T able 1. Column characteristics in terms of retention time and detector response on equal weight basis.

\begin{tabular}{lccccc}
\hline & $\begin{array}{c}\text { Standard } \\
\text { solution } \\
\mathrm{mg} / \mathrm{l}\end{array}$ & $\begin{array}{c}\text { Relative } \\
\text { retention } \\
\text { time }\end{array}$ & $\begin{array}{c}\text { Relative } \\
\text { detector } \\
\text { response }\end{array}$ & $\begin{array}{c}\text { Standard } \\
\text { error of } \\
\text { the mean } \\
\text { (n=40) }\end{array}$ & F value \\
\hline Acetic acid & 3785 & 0.151 & 0.449 & 0.0043 & $6.84^{* \cdots *}$ \\
Propionic acid & 1016 & 0.246 & 0.687 & 0.0052 & $5.14^{* *}$ \\
Isobutyric acid & 238 & 0.335 & 0.824 & 0.0059 & $1.98 \mathrm{~ns}$ \\
Butyric acid & 480 & 0.400 & 0.780 & 0.0041 & $1.49 \mathrm{~ns}$ \\
Isovaleric acid & 293 & 0.563 & 0.841 & 0.0049 & $4.20^{* *}$ \\
Valeric acid & 268 & 0.681 & 0.890 & 0.0029 & $0.89 \mathrm{~ns}$ \\
Isocaproic acid & 608 & 1.000 & 1.000 & - & - \\
\hline
\end{tabular}

** : $\mathrm{P}<0.001, \quad *$ : $\mathrm{P}<0.01, \quad$ ns: non significant.

* The work was carried out with support from the Danish Agricultural and Veterinary Research Council. 
for calculations and to control the function of the analytical equipment.

The linearity of the detector response was found satisfactory with respect to the applied range of concentration. This makes it possible to calculate the content of the individual fatty acids in a sample, analyzed by using internal standard as follows, e. g. acetic acid:

$\mathrm{mM}$ acetic acid in rumen fluid $=\mathrm{A} \backslash \mathrm{X} \times \mathrm{C} \times \mathrm{D} \times \mathrm{E}$ where

$\mathrm{A}=\frac{\text { peak area for acetic acid }}{\text { peak area for internal standard }}$

$B=\mathbf{m g}$ internal standard in sample prepared for analysis

$\mathrm{C}=\frac{\text { volume of sample prepared for analysis }}{\text { volume of rumen fluid }}$

$\mathrm{D}=\frac{1}{\text { mol. wt. of acetic acid }}$

$\mathbf{E}=\frac{1}{\mathrm{R}(\mathrm{w} / \mathrm{w})}$

Three solutions with a total concentration of 60,90 or 120 mM VFA, but constant molar proportions as shown in Table 2, were used in a test of recovery. The results from 10 replicate analyses of each solution, expressed as average values, displayed an accuracy ranging from 99.1 to $102.7 \%$ (Table 2), which agrees with the results by Ranff (1973), who obtained a range of recovery from 97.3 to $102.8 \%$ using gas liquid chromatography with Tween 80 as liquid phase.

T a b le 2. Recovery of fatty acids in solutions with a total concentration of VFA ranging from 60 to $120 \mathrm{mmol} / \mathrm{l}$.

\begin{tabular}{lccc}
\hline & $\begin{array}{c}\text { Molar composition } \\
\text { of test solutions } \\
\%\end{array}$ & $\begin{array}{c}\text { Recovery of } \\
\text { concentration } \\
\%\end{array}$ & $\begin{array}{c}\text { Standard } \\
\text { error of } \\
\text { the mean } \\
(\mathbf{n}=30)\end{array}$ \\
\hline Acetic acid & 75.10 & 99.1 & 0.38 \\
Propionic acid & 16.98 & 99.7 & 0.33 \\
Isobutyric acid & 0.73 & 101.8 & 4.3 \\
Butyric acid & 5.82 & 99.7 & 0.24 \\
Isovaleric acid & 0.68 & 102.4 & 2.6 \\
Valeric acid & 0.69 & 102.7 & 2.0 \\
\hline
\end{tabular}


T a b l e 3. Reproducibility from 12 replicate analyses of a rumen fluid sample.

\begin{tabular}{|c|c|c|c|c|}
\hline & $\begin{array}{c}\text { Concentration } \\
\text { mmol/1 }\end{array}$ & $\begin{array}{l}\text { Standard } \\
\text { error of } \\
\text { the mean }\end{array}$ & $\begin{array}{c}\text { Molar } \\
\text { percentage }\end{array}$ & $\begin{array}{l}\text { Standard } \\
\text { error of } \\
\text { the mean }\end{array}$ \\
\hline Acetic acid & $66.16 \pm 0.7 .0$ & 0.20 & $76.43 \pm 0.37$ & 0.11 \\
\hline Propionic acid & $13.52 \pm 0.51$ & 0.15 & $15.61 \pm 0.38$ & 0.11 \\
\hline Isobutyric acid & $0.54 \pm 0.03$ & 0.01 & $0.62 \pm 0.03$ & 0.01 \\
\hline Butyric acid & $5.28 \pm 0.11$ & 0.03 & $6.10 \pm 0.09$ & 0.03 \\
\hline Isovaleric acid & $0.68 \pm 0.03$ & 0.01 & $0.79 \pm 0.03$ & 0.01 \\
\hline Valeric acid & $0.38 \pm 0.04$ & 0.01 & $0.44 \pm 0.05$ & 0.01 \\
\hline Total VFA & $86.57 \pm 1.26$ & 0.36 & - $\quad-$ & - \\
\hline
\end{tabular}

A rumen fluid sample was taken from a heifer fed hay, and 12 replicate analyses were conducted to examine the precision of the analytical method, expressed as standard deviation and standard error of the means of the concentrations of the total and individual VFA and the molar percentage of the VFA mixture. The obtained results are presented in Table 3, which shows a high reproducibility. The coefficient of variation, e. g., calculated for the total VFA is 1.45 . It can be concluded that the method is useful for a quantitative analytical purpose.

\section{Kurt Jensen}

The Department of Animal Nutrition, Royal Veterinary and Agricultural University, Copenhagen, Denmark.

\section{REFERENCES}

Jensen, $K$.: Gas-solid adsorption chromatographic determination of short-chain fatty acids in rumen fluid. Acta vet. scand. 1973, 14, 335-337.

Ranfft, K.: Gaschromatographische Bestimmung kurzkettiger, flüchtiger Fettsäuren im Pansensaft. (Determination by gas chromatography of short-chain fatty acids in ruminal fluid). Arch. Tierernähr. 1973, 23, 343-352.

(Received June 28, 1974).

Reprints may be requested from: Kurt Jensen, Department of Animal Nutrition, Royal Veterinary and Agricultural University, Bülowsvej 13, DK-1870 Copenhagen V, Denmark. 